\title{
A Klinikák finanszírozásának egyes kérdései
}

\author{
Fábos Zoltán dr.
}

Pécsi Tudományegyetem KK, Urológiai Klinika, Pécs (igazgató: Szántó Árpád dr.)

$S_{n}^{20}$ zepesváry Zsolt kitúnően rávilágított a hazai finanszírozás hiányosságaira egy megyei kórház szemszögéből.

Az urológiai fekvőbeteg-finanszírozás a klinikákon is hasonló problémákat okoz, de ezen felül még olyan speciális nehézségekkel is meg kell küzdeni, mint az oktatás és a kutatás.

A másik probléma a klinikák esetén a fenntartás és finanszírozás kettőssége. Az orvoskarok fenntartója az Oktatási Minisztérium és a finanszírozást is biztosítja, míg a Klinikai Központok fenntartója az Emberi Erőforrás Minisztériumon belül az Egészségügyi Államtitkárság, de a betegellátást a NEAK finanszírozza.

Minden ellátási szinten gondot okoz a szövődmények ellátása, igenis bele kell számolni a súlyszám kialakításánál a szövődmények lehetőségét. Korábbi HBCS-verziókban (HBCS1.0 - HBCS 4.1) szerepeltek olyan HBCS-k, amelyek kísérőbetegségekkel kiegészítve magasabb súlyszámot jelentettek. Ez nem pontosan a szövődményeket vette figyelembe, azonban közvetve mégis megjelent a finanszírozásban (pl.: egy cukorbetegség esetén fokozott kockázattal fellépő húgyúti fertőzés többlet antibiotikum-költségét fedezte). Sajnálatos módon ezen HBCS-k kikerültek a rendszerből.

A következő általános, mindenkit érintő probléma az eszközök amortizációja. Ebben a kérdésben a fenntartó szerepe óriási, és azért jelentős különbségek vannak egyes osztályok felszereltsége között. Amíg a megyei és városi kórházak az önkormányzatok tulajdonába tartoztak, sokkal heterogénebb volt az eszközpark. Voltak olyan városi kórházak, ahol az önkormányzat jelentős anyagi forrást biztosított eszközvásárlásra (jobban múködött a lobbi), és voltak olyan megyei kórházak, ahol minimális összeget fordítottak az eszközbeszerzésre. Akkor a kórházak között létezett az a különbség, hogy egyes helyeken 4 dimenziós UH volt, máshol reziduális vizeletet nem lehetett megítélni az UH-val. Amióta az állam átvette az önkormányzati kórházakat, azóta kampányszerú beszerzések eredményezik a full HD-s videorendszert és a félvak TUR-os optikákat egy kórházon belül. A klinikákon jelenleg még rosszabb a helyzet, ugyanis azt, hogy az eszközvásárlásra fordítható kevés pénzből mi jut a klinikákra, az orvoskar dékánjának és a Klinikai Központ elnökének csatája dönti el.

A harmadik nagy kérdés egy osztály nyereséges vagy veszteséges múködtetése. Ez ugyanis meghatározza egy osztály sorsát az adott kórházban. A kórházigazgatóknak az érdeke, hogy nyereséges legyen a kórház, ezért azokat a szakmákat helyezik előtérbe, amely szakmák nem „termelnek” veszteséget. Ebből a szempontból nagyon nagy eredmény, hogy a Győri Urológiai osztály nyereséges és ebben nyilvánvalóan jelentős szerepe van az osztályvezetőknek. Sajnos azt kell mondanom, hogy az urológiai szakma általában veszteségesen múködtethető. 2014-ben tartott felmérés alapján mind a 4 egyetemi klinika és 8 megyei kórház veszteséges volt.

A nyereséges osztály kritériumai nincsenek lefektetve és nem egységesek. Például 1995-ben a Pécsi Klinikáról nyolcan elmentünk Götz professzor úr irányításával megnézni, hogy akkor az ország egyetlen nyereséges osztálya mitől nyereséges. Egyszerú volt a képlet. Ha teljesítették a havi 120 súlyszámot, akkor nullszaldósok voltak, az efeletti súlyszámbevétel volt a nyereség. A kiadási oldalt nem vették figyelembe.

Nézzük meg, milyen tényezők befolyásolják alapvetően az eredményességet. A központi elvonás alapvetően meghatározó egy osztály nyereséges vagy veszteséges megítélésében. A jelenleg is hatályban lévő 50 elemú HBCS alapján a központi elvonás kb. 10\%. Volt olyan időszak a Pécsi Urológiai Klinikán, amikor ez megközelítette a 40\%-ot. Nyilván lehetetlen ezt kitermelni az urológiai HBCS-ből.

A másik meghatározó kérdés a bérköltség, ezen belül a bennalvó ügyeletesek bérköltsége. Jelenleg Dunántúlon két helyen (Pécs, Szombathely) múködik a bennalvós ügyeletes rendszer. Ez jelentős többletkiadás a múködtetésben.

A harmadik meghatározó tényező az urológiai nagymútétek száma egy osztály eredményében. Minél több radikális mútétet (cystectomia, radikális prostatectomia, posztkemoterápiás RLA, pénisztumorok radikális mútétei) végzünk, annál nagyobb lesz a veszteségünk. Ahol csak „kismútéteket" végeznek, kisebb a veszteség mértéke.

Ezek után a megfelelő múködés feltételeinek biztosítását nagyon jól összefoglalta a szerző, de biztos, hogy ez a „szerényebb" változat a szükséges költségeknek.

A korrekt HBCS-súlyszám megállapításához nagyon aktuális lenne egy országos költségfelmérés. Ezenfelül meg kell határozni a fenntartóknak, hogy mennyi forrást biztosítanak a biztonságos eszközpark múködtetéséhez tekintettel arra, hogy nem akarják a HBCS-be beemelni az amortizáció költségét. Természetesen egyszerúbb és biztonságosabb lenne, ha el lehetne érni, hogy az amortizáció bekerüljön a HBCS-be. 